\title{
First Occurrence and Re-description of Aculus epiphyllus (Nalepa) (Acariformes: Eriophyoidea) from Fraxinus pennsylvanica in Europe
}

\author{
G. RIPKA ${ }^{1}$, M. KORDA ${ }^{2}$ and Á. SZABÓ ${ }^{3}$ \\ ${ }^{1}$ National Food Chain Safety Office, Directorate of Plant Protection, Soil Conservation and Agri-environment, \\ H-1118 Budapest, Budaörsi út 141-145, Hungary \\ ${ }^{2}$ Department of Botany and Nature Conservation, Faculty of Forestry, University of Sopron \\ H-9400 Sopron, Bajcsy-Zsilinszky utca 4, Hungary \\ ${ }^{3}$ Department of Entomology, Faculty of Horticultural Science, Szent István University, \\ H-1118 Budapest, Villányi út 29-43, Hungary
}

(Received: 8 November 2019; accepted: 22 January 2020)

\begin{abstract}
Aculus epiphyllus (Nalepa, 1892) is reported from green ash in Europe for the first time. Ash rust mite has never been found on green ash, and we therefore re-describe and illustrate the female and male, and describe the nymph. The species was collected from the underside of the leaflets of the introduced ash species, Fraxinus pennsylvanica Marshall (Oleaceae) in Hungary.
\end{abstract}

Keywords: Eriophyidae, Aculus, green ash, new host, Hungary.

Eight eriophyoid mite species are known from species of ash (Fraxinus spp.), viz. Aceria fraxini (Garman), Aceria fraxinicola (Nalepa), Aceria fraxiniflora (Felt), Aceria fraxinivora (Nalepa), Aculus epiphyllus (Nalepa), Aculus fraxini (Nalepa), Tegolophus califraxini (Keifer) and Tegonotus collaris Nalepa (Amrine and Stasny, 1994). Five of these species cause galls, erineum, leaf deformation, bronzing or rust exclusively on leaves. For example, Aceria fraxini causes elongate bead-galls on several species of North American Fraxinus, and A. fraxinicola causes nail-galls on the leaves of European ash (Fraxinus excelsior). Two species, A. fraxiniflora and $A$. fraxinivora, are known to cause galls on inflorescences (Amrine and Stasny, 1994; Davis et al., 1982). The latter species is well-known causing cauliflower-like deformation of the inflorescence and fruits on Fraxinus excelsior, F. ornus and F. angustifolia (Ripka, 2007).

From European ash (F.excelsior) Nalepa $(1892,1894,1911)$ described two leaf-inhabiting Aculus species, viz. Aculus epiphyllus (Nalepa, 1892), which causes erineum and rust, and Aculus fraxini (Nalepa, 1894), which causes leaf edge rolling. 
In Hungary 7 species have been known from Fraxinus spp., viz. Aceria fraxinicola, Aceria fraxiniflora, Aceria fraxinivora, Aculus epiphyllus, Aculus fraxini, Tegolophus califraxini and Tegonotus collaris.

Herein we report on our discovery of a species of the genus Aculus Keifer, 1959 found on the under surface of the leaves of Fraxinus pennsylvanica, which is an introduced species of ash from North America. Prior to this paper, no eriophyoid species have been recorded from the foliage of green ash (Amrine and Stasny, 1994; Davis et al., 1982). In Hungary, Korda et al. (2019) have recently described Aceria fraxiniflora from the globular sponge-like galls on the inflorescences and fruits of $F$. pennsylvanica. Because the description of Aculus epiphyllus given by Nalepa (1894) is incomplete we re-described the female and male and described the nymph, and provide morphometric data for the differences between our examined specimens and the data available from literature.

\section{Materials and Methods}

The eriophyoid mite fauna of green ash, Fraxinus pennsylvanica Marshall, was studied from plant samples collected in Balf, Györ-Moson-Sopron county (Western Hungary), in May 2019. The plant material was collected in paper and plastic bags, then returned to the laboratory and examined under a stereo dissecting microscope (Zeiss Stemi 2000-C). After clearing the eriophyoid mites in lactic acid they were mounted in Keifer's F-medium with sorbitol on microscope slides (Keifer, 1975). Specimens were examined with the aid of a research phase contrast compound microscope (Nikon Eclipse E600) equipped with a drawing tube (Nikon Y-IDT). A Zeiss Axio Imager A2 microscope was used for making digital microscopic images on slide mounted specimens. The morphology of Aculus epiphyllus was also investigated with the aid of scanning electron microscope (SEM) (Zeiss EVO 40 XVP) at the Research Centre for Natural Sciences, Hungarian Academy of Sciences, Budapest. Live mites were collected individually with a fine entomological needle from fresh plant parts under a stereomicroscope and placed on the SEM holder without fixation, dehydration and sputter-coating.

The generic classification was made according to Amrine et al. (2003) together with further updating. The terminology and setal notation used in the morphological descriptions follow Lindquist (1996). The number of measured specimens (n) is given in parentheses following the body length. All measurements of mites were made according to Amrine and Manson (1996) and are given in micrometers. Measurements and means are rounded off to the nearest integer. All measurements, unless specified otherwise, are lengths. For females the mean and the ranges, for males and nymphs the data of ten and five specimens are given, respectively.

The scientific name of host plant is used according to Király (2009), and The Plant List (2013). 


\section{TAXONOMY \\ Superfamily ERIOPHYOIDEA Nalepa \\ Family ERIOPHYIDAE Nalepa \\ Subfamily PHYLLOCOPTINAE Nalepa \\ Tribe ANTHOCOPTINI Amrine and Stasny \\ Genus Aculus Keifer}

Aculus epiphyllus (Nalepa, 1892)

(Figs 1-11)

Phyllocoptes epiphyllus Nalepa, 1892: 122.

Phyllocoptes epiphyllus Nalepa, 1894: 298-299.

Vasates epiphyllus - Farkas, 1965: 93.

Vasates epiphyllus - Farkas, 1966: 86.

Aculus epiphyllus - Davis et al. 1982: 103.

Aculus epiphyllus - Amrine and Stasny, 1994: 119.

Re-description. Female - Body dirty yellowish white, spindle form, 183 (157$208, \mathrm{n}=10), 73(71-75)$ wide, $76(72-80)$ thick. Gnathosoma 23 (20-26), projecting obliquely downwards; dorsal palp genual setae $d 5$ (5-6), unbranched, pedipalp coxal setae ep 2 (2-3). Chelicerae 17 (16-23). Prodorsal shield 47 (42-50), 54 (48-60) wide, semicircular with frontal lobe 6 (5-7); shield pattern composed of lines of granules: two faint incomplete admedian lines, diverging posteriorly, more widely separate on rear $1 / 3$, two faint incomplete submedian lines; faint incomplete median line on rear $1 / 3$; median and admedian lines connected by a faint V-shape transverse line at rear 1/4; admedian and submedian lines connected by a short transverse line on each side at anterior $1 / 3$. All lines are ridges bearing rounded microtubercles. Small granules between submedian lines and shield margin. Ornamentation of prodorsal shield is considerably variable, e.g. size of median and admedian lines, and the shield design weakly expressed: a part of the population with obscure irregular lines of granules on prodorsal shield. Tubercles of scapular setae $s c$ on rear shield margin, 37 (36-38) apart, diverging, scapular setae sc 21 (20-24), directed rearwards. Granules situated in lateral rows on epicoxal areas, i.e. laterally between shield margin and dorsal coxae of legs I and II (sensu Chetverikov and Craemer, 2015).

Legs with all usual segments and setae present. Leg I (foreleg) 36 (31-40), femur 10 (10-11), basiventral femoral seta $b v 10$ (9-10), genu 5 (5-6), antaxial genual seta $l^{\prime \prime} 23$ (22-24), tibia 8 (8-9), distally with a single spinule $2(2-3)$, paraxial tibial seta $l^{\prime}$ located at $1 / 3$ from dorsal base, 4 (3-5), very thin, tarsus 7 (6-8), unguinal tarsal setae $u^{\prime} 2(2-3)$, solenidion $\omega 6$ (5-7), distally knobbed, slightly curved, empodium simple, bilaterally symmetrical, 6 (5-6), 4-rayed. Leg II (rear leg) 33 (29-37), femur 10 (8-12), basiventral femoral seta $b v 12$ (12-13), genu 5 (4-5), antaxial genual seta $l$ " 10 (9-11) very thin, tibia 6 (5-7), distally with a single spinule 2 (1-2), tarsus 7 (6-8), unguinal tarsal setae $u^{\prime} 2$ (1-3), solenidion $\omega 7$ (5-8), distally knobbed, slightly curved, empodium simple, bilaterally symmetrical, 6 (5-7), 4-rayed.

Coxigenital area with 9 (8-10) microtuberculate semiannuli. Coxisternae I and II with dim lines of minute granules, and dense granules; anterior seta on coxisternum I, $1 b 9(8-11)$, tubercles setae $1 b 10(10-11)$ apart, proximal seta on coxisternum I, $1 a 15$ 


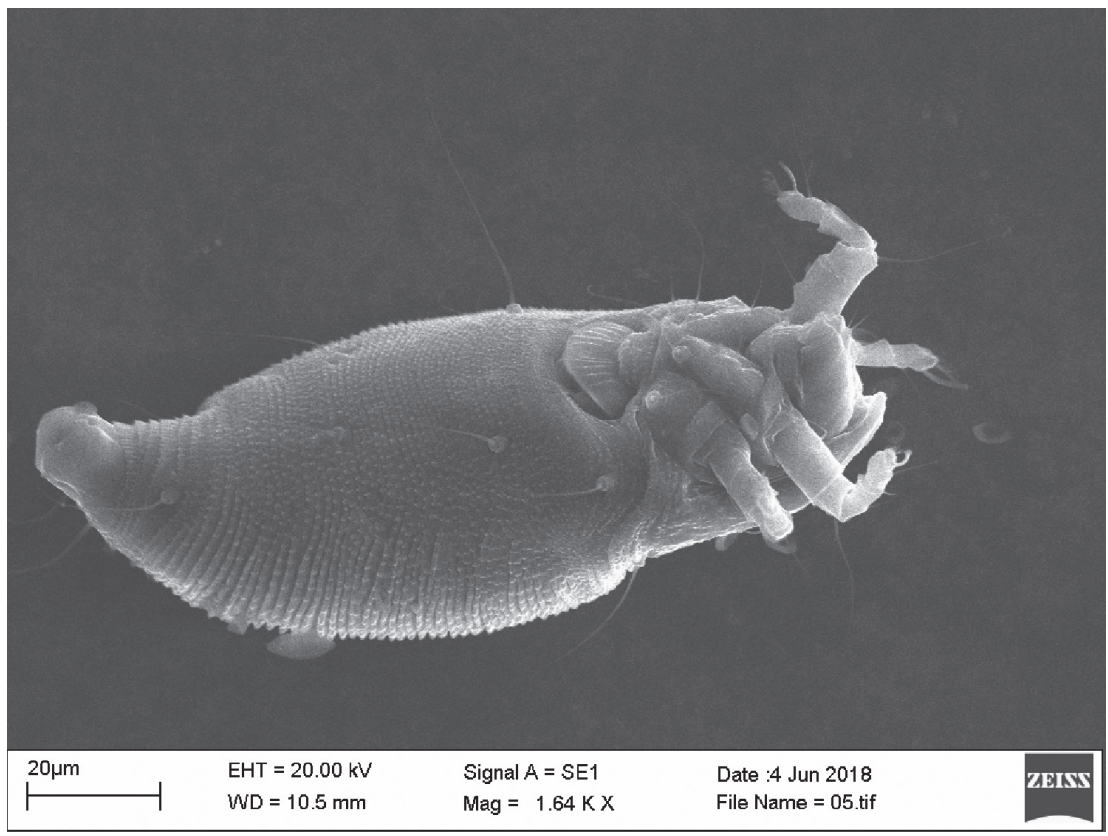

Fig. 1. SEM micrograph of Aculus epiphyllus, ventrolateral view of female. (Photo: Dr. László Szabó)

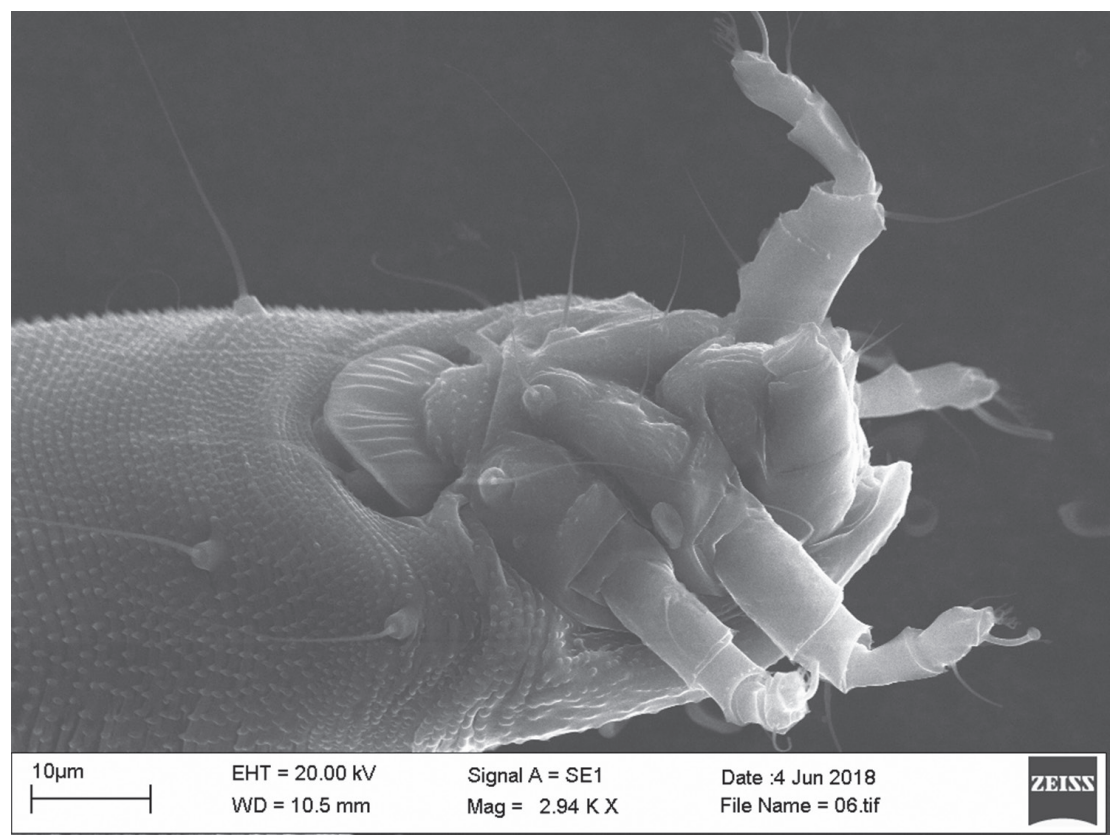

Fig. 2. SEM micrograph of Aculus epiphyllus, anterior region of female: gnathosoma, legs and coxigenital region, in ventrolateral view. (Photo: Dr. László Szabó) 


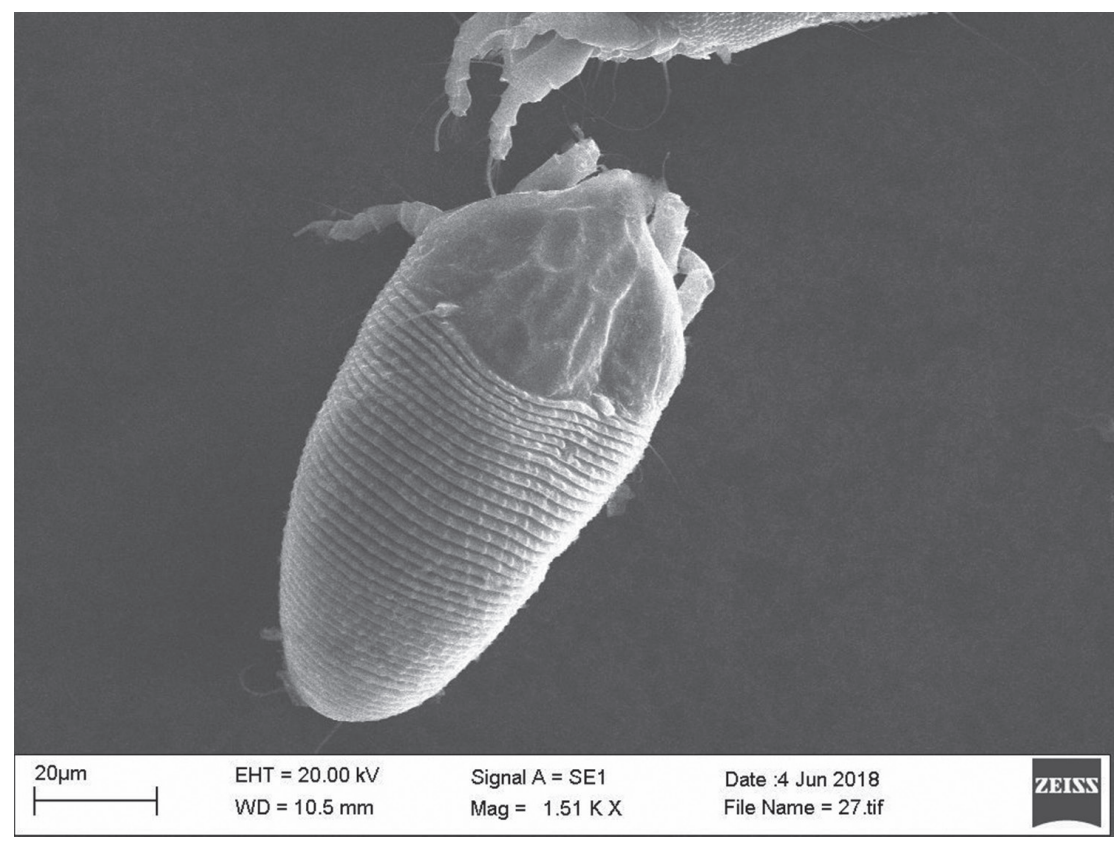

Fig. 3. SEM micrograph of Aculus epiphyllus, dorsal view of female. (Photo: Dr. László Szabó)

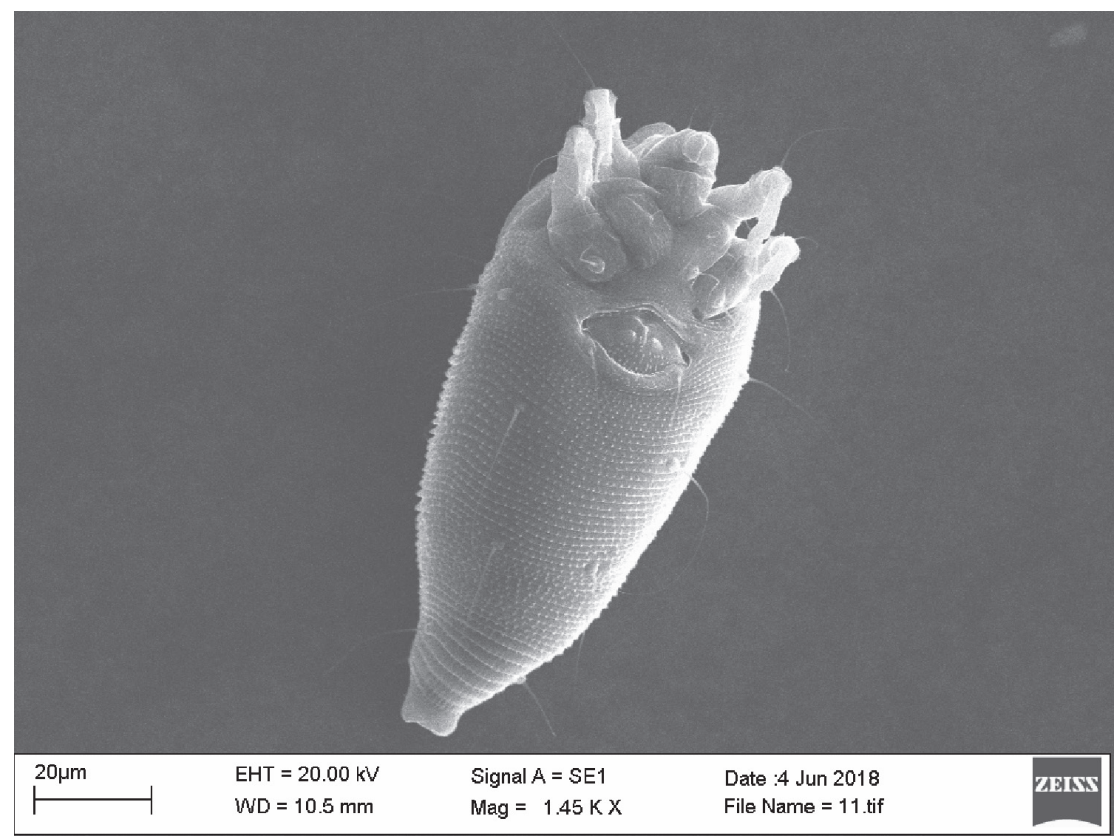

Fig. 4. SEM micrograph of Aculus epiphyllus, ventral view of male. (Photo: Dr. László Szabó) 
(15-16), tubercles setae $1 a 10$ (9-10) apart, proximal seta on coxisternum II, $2 a 43$ (4243), tubercles setae $2 a 26$ (26-27) apart. Subcapitular plate rounded with tiny granules. Prosternal apodeme 8 (7-10).

Opisthosoma with 49 (38-57) microtuberculate dorsal, 69 (64-74) finely microtuberculate ventral semiannuli. Microtubercles thin and elongate, more sparse dorsally, smaller, more dense and pointed ventrally. Last 4-5 dorsal annuli with minute microtubercles on rear annular margin. Last 4-5 ventral annuli with linear microtubercles. Opisthosomal setae $c 232$ (29-45), on annulus 13 (11-15), 54 (53-54) apart; opisthosomal setae

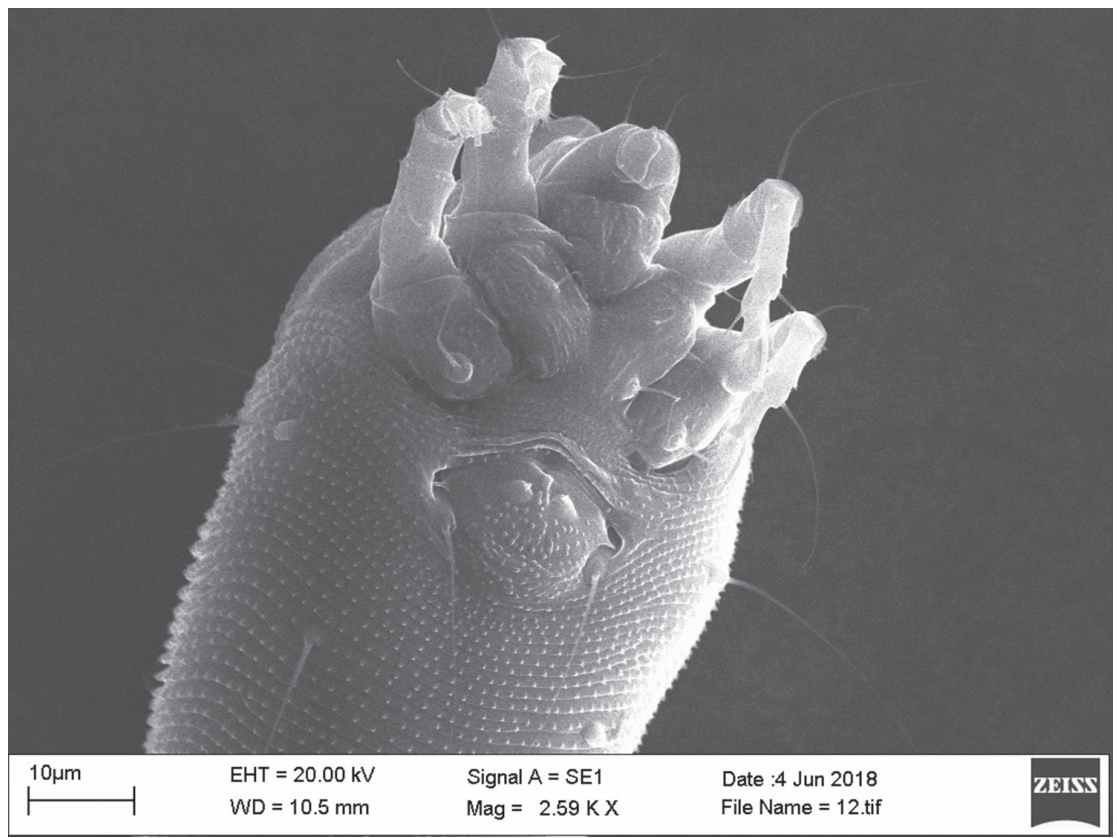

Fig. 5. SEM micrograph of Aculus epiphyllus, anterior region of male: gnathosoma, legs and coxigenital region in ventrolateral view. (Photo: Dr. László Szabó)

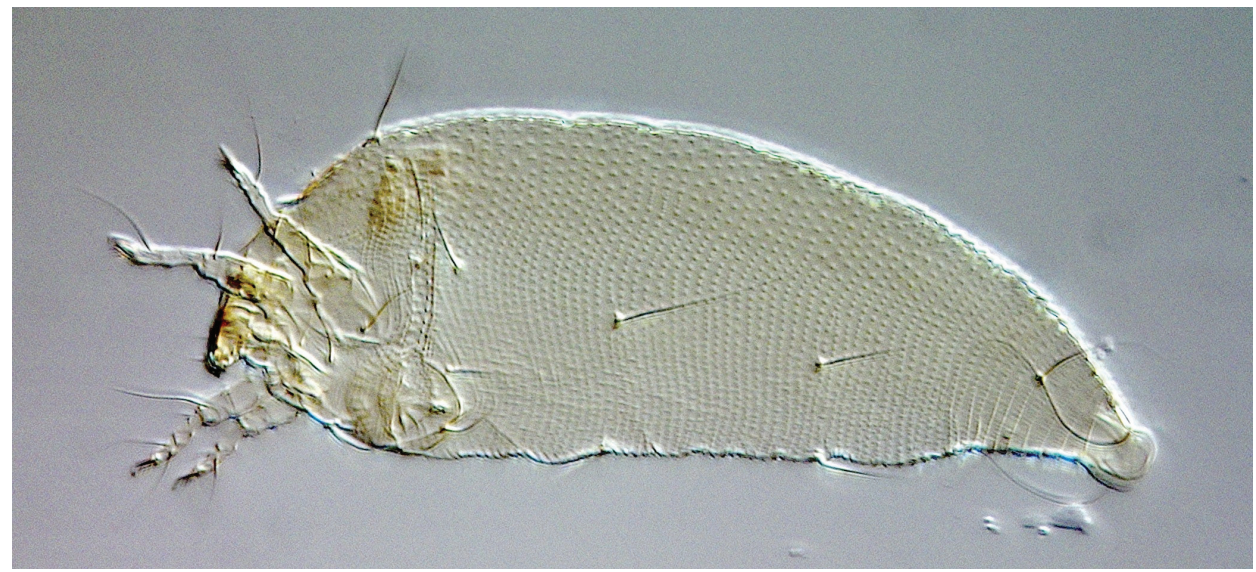

Fig. 6. Digital micrograph of Aculus epiphyllus, female in lateral view (Photo: Árpád Szabó) 


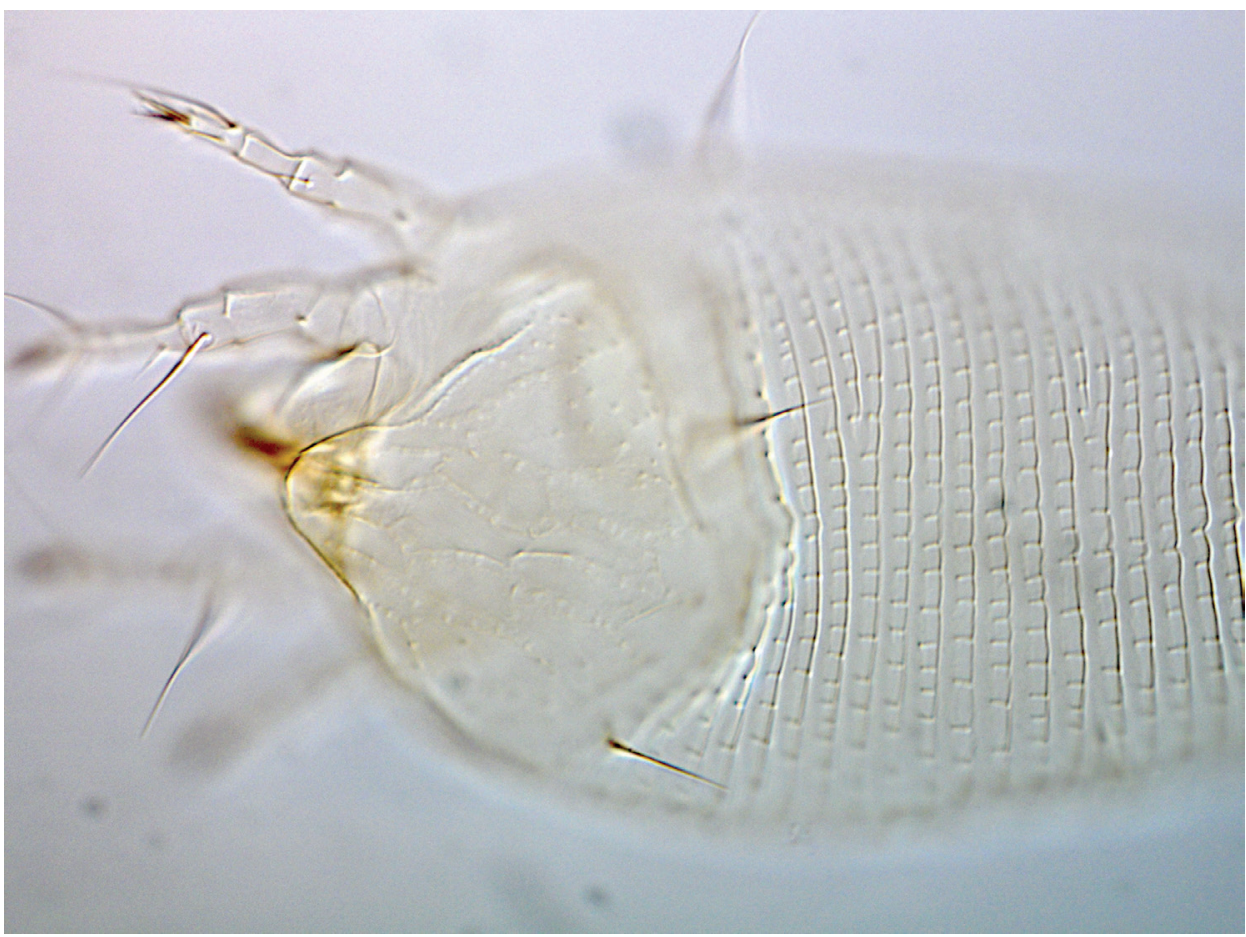

Fig. 7. Digital micrograph of Aculus epiphyllus, prodorsal shield and anterior opisthosoma of female, in dorsal view (Photo: Árpád Szabó)

$d 63$ (50-70), on annulus 27 (25-28), 36 (34-37) apart; opisthosomal setae e 21 (19-23), on annulus 46 (42-48), 19 (18-20) apart; opisthosomal setae $f 30$ (26-36), on annulus 65 (60-70), or 5 (4-5) from the rear, 24 (23-25) apart. Opisthosomal setae $h 2104$ (100-110), very thin at apex, 11 (10-12) apart; opisthosomal setae $h 12$ (2-3), 7 (7-8) apart. Anal lobes normal, with longitudinal ridges.

Genital plate 17 (15-20), 24 (23-26) wide. Female genital coverflap with 11 (1013) longitudinal ridges; coxisternal III setae $3 a 16$ (15-16) apart, 19 (14-27), very thin. (Figs 1-3) (Figs 6-9).

MALE - Similar to female, dirty yellowish white, 165-210 $(n=5), 65-70$ wide, 59-65 thick. Gnathosoma 17-20, projecting obliquely downwards; dorsal palp genual setae $d 3-4$, unbranched; pedipalp coxal setae ep 1 (no range). Chelicerae 14-17. Prodorsal shield 42-46, 55-60 wide, semicircular, with frontal lobe 5-6, ornamentation similar to female. Tubercles of scapular setae $s c$ on rear shield margin, 33-38 apart, diverging, scapular setae $s c$ 20-23, directed to the rear. Legs with all usual segments and setae present. Leg I 31-35, femur 10 (no range), basiventral femoral setae $b v 8-10$, very fine, genu 5-6, antaxial genual setae $l$ " $16-19$, tibia 7-8, distally with a single paraxial spinule 2 (2-3), paraxial tibial setae $l^{\prime}$ located at $1 / 3$ from dorsal base, $4-5$, very fine, tarsus $6-7$, unguinal tarsal setae $u^{\prime} 3-4$, solenidion $\omega 6-7$, slightly curved, distally knobbed, empodium simple, bilaterally symmetrical, 5-6, 4-rayed. Leg II 28-32, femur 10 (no range), basiventral femoral setae $b v$ 10-11, very fine, genu 5 (no range), antaxial genual setae $l^{\prime \prime} 7-9$, very fine, tibia $6-7$, distally with a single paraxial spinule 2 (1-2), tarsus $6-7$, unguinal 


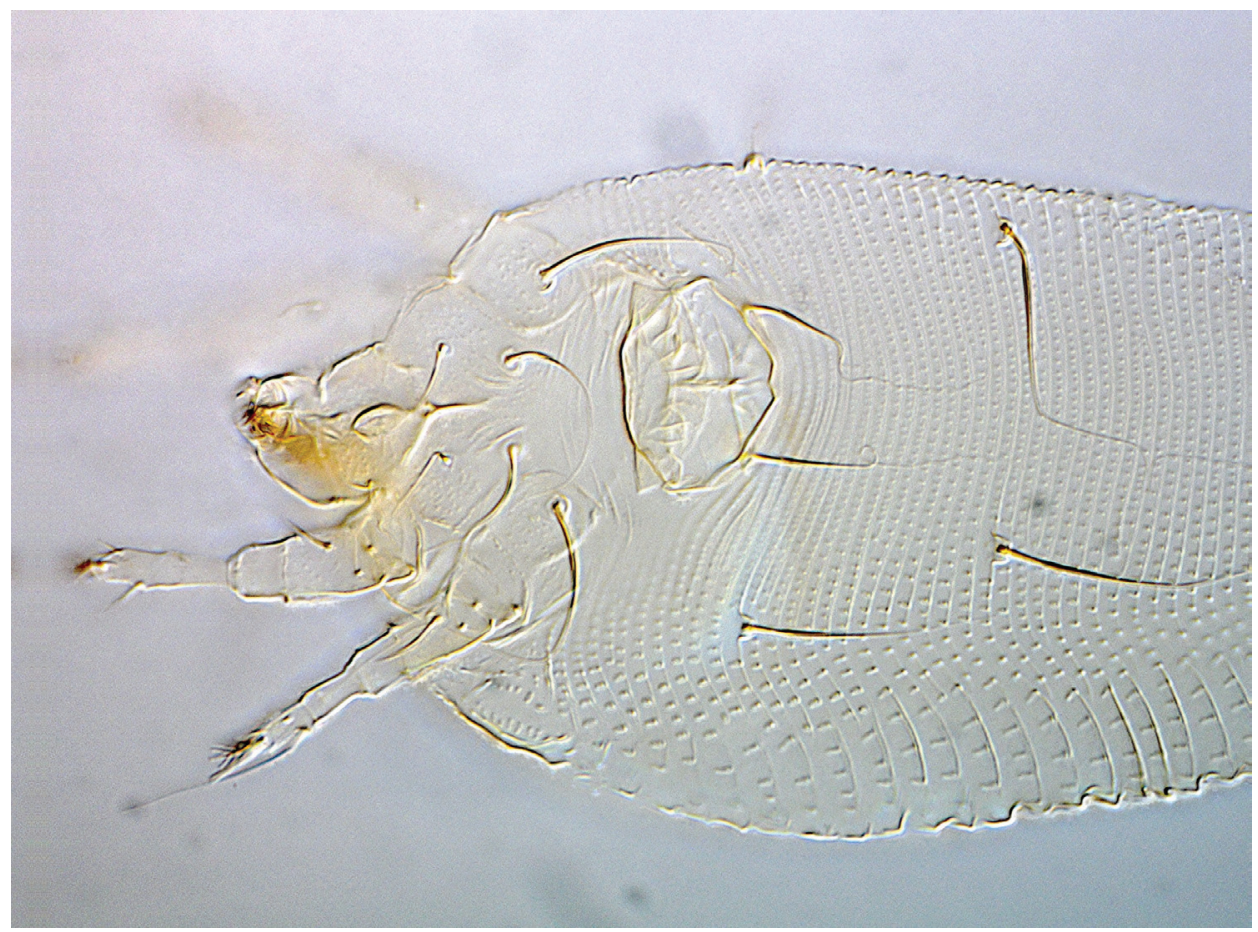

Fig. 8. Digital micrograph of Aculus epiphyllus, coxigenital region of female (Photo: Árpád Szabó)

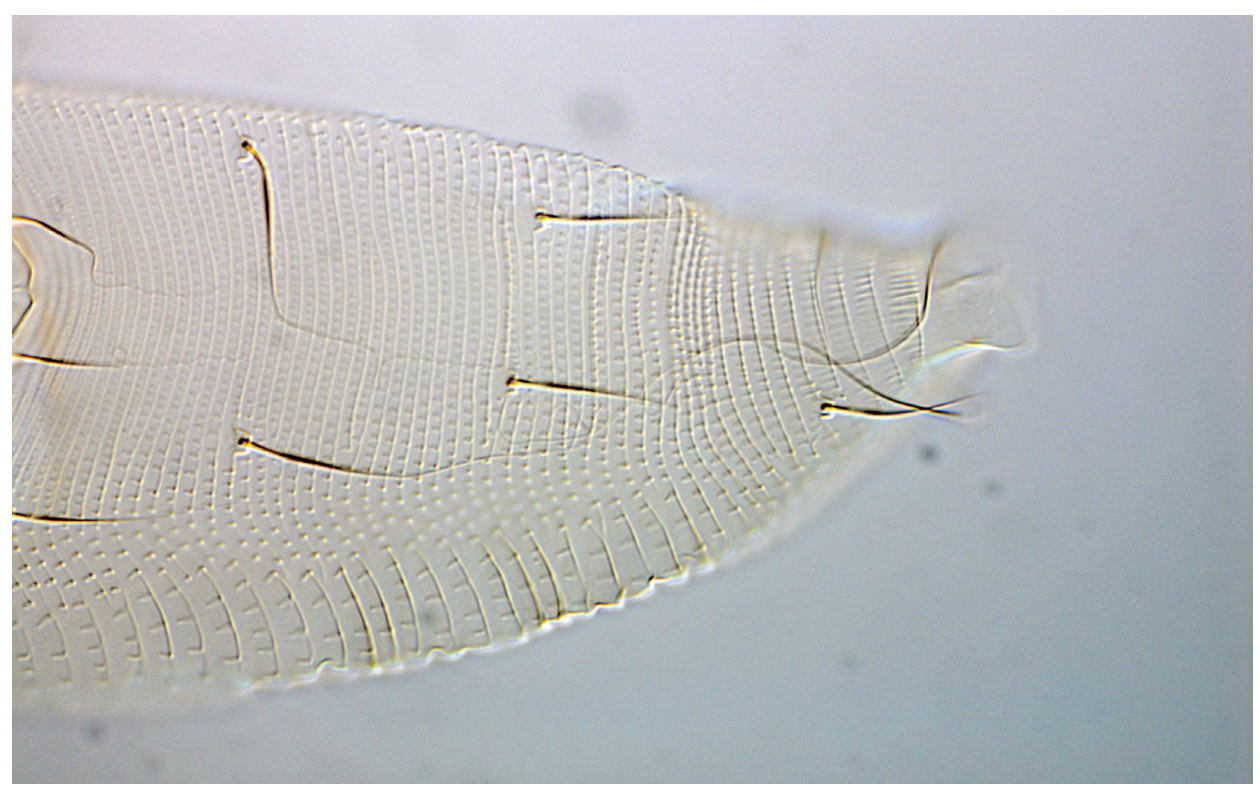

Fig. 9. Digital micrograph of Aculus epiphyllus, posterior part of female opisthosoma in ventrolateral view (Photo: Árpád Szabó) 


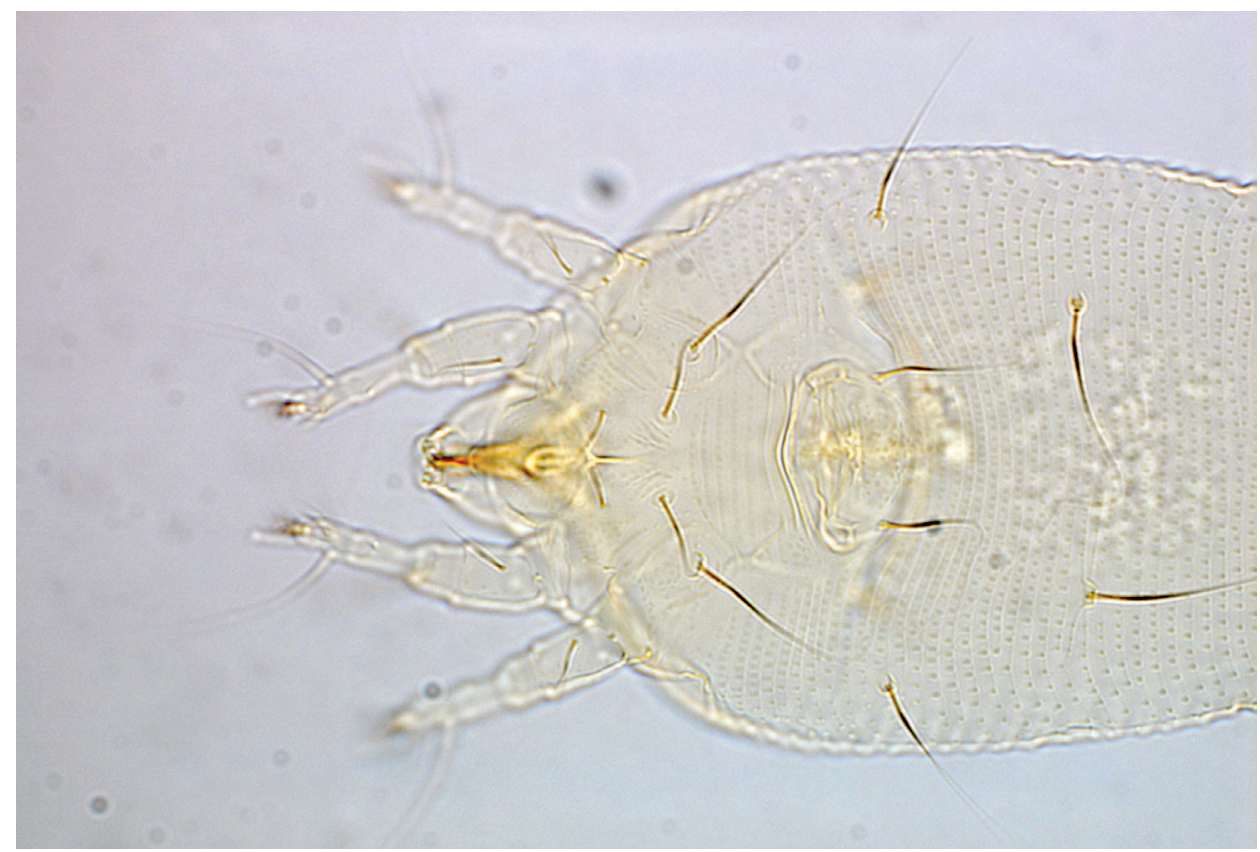

Fig. 10. Digital micrograph of Aculus epiphyllus, coxigenital region of male (Photo: Árpád Szabó)

tarsal setae $u^{\prime} 2-3$, solenidion $\omega 7-8$, slightly curved, distally with a minute knob, empodium simple, bilaterally symmetrical, 5-6, 4-rayed. Coxisternae I and II with dim lines of minute granules, and dense granules; setae $1 b$ 8-10, 10-11 apart, setae $1 a$ 11-20, 9-10 apart, setae 2a 33-44, 22-24 apart, all very fine. Subcapitular plate anteriorly rounded, with minute granules. Prosternal apodeme 6-7. Coxigenital area with 7-9 microtuberculate semiannuli. Opisthosoma with 37-49 microtuberculate dorsal, 65-70 finely microtuberculate ventral annuli. Posterior 4 dorsal annuli with minute microtubercles. Thin and elongate microtubercles more sparse dorsally, smaller, more dense and pointed ventrally, except for 4-5 ventral annuli of anal lobes, which are elongate and linear. Caudal lobe normal in size and shape. Setae $c 2$ 24-28, on ventral annulus 12-14, 50-60 apart; setae $d$ 35-52, on ventral annulus 24-26, 31-36 apart; setae $e$ 18-23, on ventral annulus 41-44, 18-22 apart; setae $f 25-30$, on ventral annulus 61-66, or 5 from rear, 25-27 apart. Setae h2 80-97, 9-10 apart; setae $h 1$ 2-3, 5-6 apart. Genitalia 13-18, 20-23 wide, posterior $2 / 3$ with minute granules, setae $3 a$ 14-20, 17-20 apart, in progenital chamber tiny eugenital setae present. (Figs 4-5) (Figs 10-11).

NYMPH - White, vermiform, 140-162 ( $\mathrm{n}=5)$, 57 wide, 50-60 thick. Gnathosoma 17-22; dorsal palp genual setae $d 1-2$; chelicerae 14-17. Prodorsal shield 33-37, 40-50 wide. Setae sc 10-12, pointing rear, 25-27 apart. Leg I 20-21, leg II 17-20. Setae $1 b$ 4-5, 8-10 apart, setae $1 a$ 7-11, 5-7 apart, setae $2 a$ 13-15, 17-18 apart. Prosternal apodeme 3-5. Opisthosoma with 40-52 dorsal, 42-54 ventral annuli. Dorsal and ventral annuli with minute microtubercles, sparse dorsally, smaller and more dense ventrally. Setae $c 2$ 9-11, on annulus 9-13; 39-41 apart; setae $d 15-19$, on annulus 18-23, 27 apart; setae $e$ 


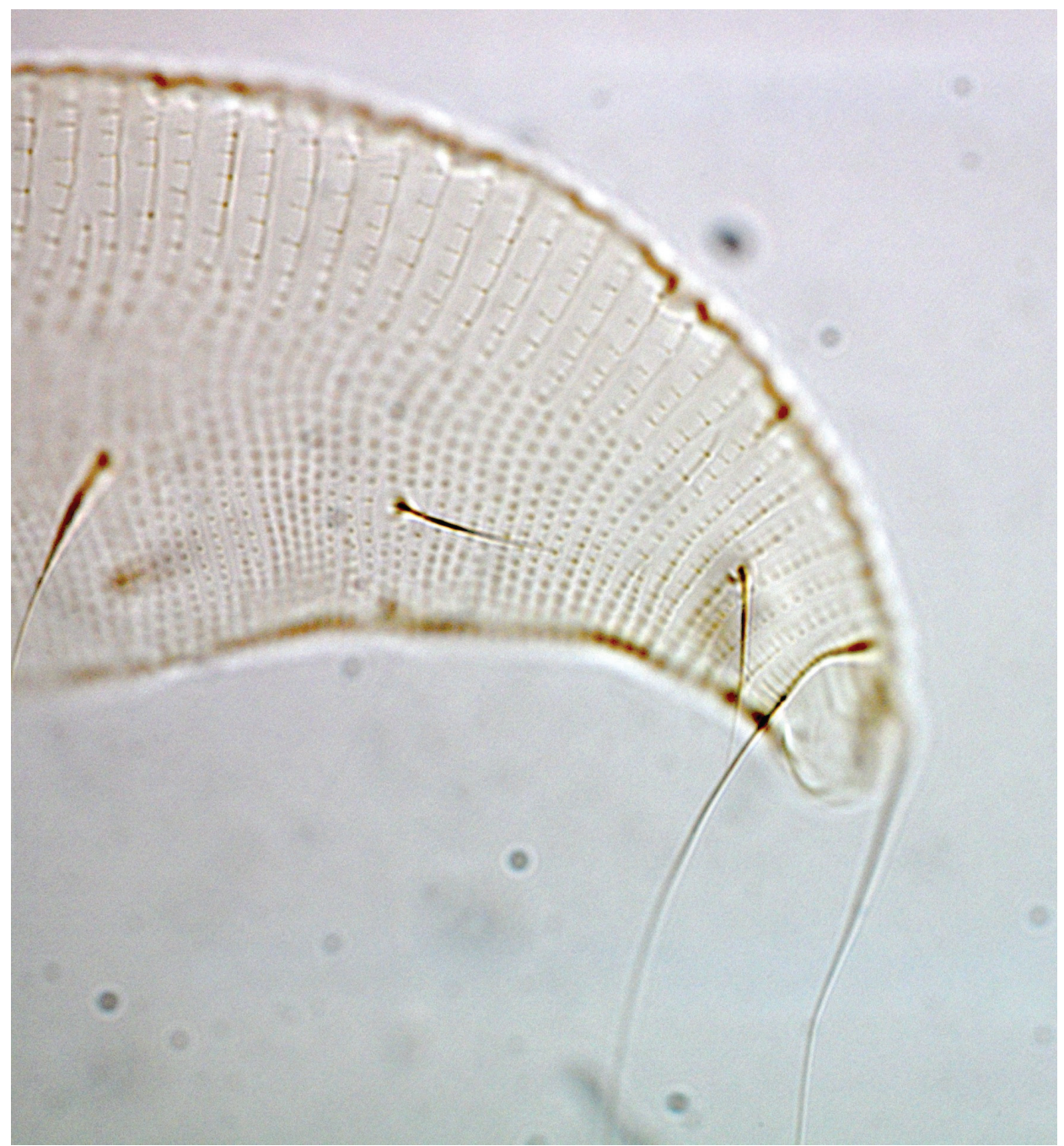

Fig. 11. Digital micrograph of Aculus epiphyllus, posterior part of male opisthosoma in lateral view (Photo: Árpád Szabó)

$12-13$, on annulus $28-35,15-16$ apart; setae $f 14-17$, on annulus $42-50$, or $4-5$ from rear, 17-20 apart. Setae $h l 1$; setae $3 a$ 6-8, 10 apart.

Host plant - Green ash, Fraxinus pennsylvanica Marshall (fam. Oleaceae). Green ash is the most widespread of the North American ash species, native to eastern and central North America, and an invasive transformer tree species in Hungary living in different plant associations, especially along rivers (Csiszár and Bartha, 2004). Green ash came to Europe in 1780, and around 1802 to Hungary (Csiszár and Bartha, 2004; Korda, 2018). Green ash is a new host plant of A. epiphyllus, and until now the first non-European Fraxinus species, which has been recorded as a host. 
Relationship to the host - This mite caused no discernible symptoms on the host. The mite was found on the underside of the leaflets, on and close to the midrib and veins. It should be noted that $64 \%$ of the adult population was male.

Hungarian locality - Balf, Győr-Moson-Sopron county (Western Hungary), in a

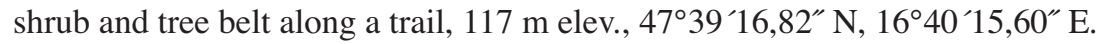

Material examined - The re-described and illustrated female among 4 females and 11 males on slide \# 1461a, 2 May 2019, coll. Mr. Márton Korda. Other specimens were collected by Mr. M. Korda in the same locality and time. The 3 slides (\#\#\# 1461b, 1461c, $1461 \mathrm{~d}$ with described males and nymphs) were prepared from this material containing 3 females, 5 males and 7 nymphs, and 8 females, 7 males and 7 nymphs, and 2 females, 9 males and 5 nymphs, resp. from the leaves of the same green ash tree. Slides are in the corresponding author's collection and deposited in the National Food Chain Safety Office, Directorate of Plant Protection, Soil Conservation and Agri-environment, Budapest, Hungary.

\section{Discussion}

This is the first complete and detailed description of males and nymphs of Aculus epiphyllus. We found different characteristics and morphometric data between the examined specimens and the literature data (Table 1). Except for the length of prodorsal shield and width of female external genitalia, the measurements of the specimens collected from $F$. pennsylvanica were considerably larger than that of the holotype given by Nalepa (1894) and specimens studied by Farkas (1966). The other European ash leaf-dwelling

\section{Table 1}

Some different characters of Aculus epiphyllus based on the literature and the examined specimens from green ash

\begin{tabular}{|c|c|c|c|}
\hline Character & $\begin{array}{l}\text { Aculus epiphyllus } \\
\text { holotype from European } \\
\text { ash (Nalepa, 1894) }\end{array}$ & $\begin{array}{l}\text { Aculus epiphyllus } \\
\text { from European ash } \\
\text { (Farkas, 1966) }\end{array}$ & $\begin{array}{l}\text { Aculus epiphyllus } \\
\text { from Green ash } \\
\text { (present study) }\end{array}$ \\
\hline Female body length & 150 & 150 & $157-208$ \\
\hline Female body width & 46 & 46 & $71-75$ \\
\hline Male body length & 110 & $110-130$ & $165-210$ \\
\hline Male body width & 40 & 44 & $65-70$ \\
\hline Length of prodorsal shield & n.d. & 48 & $42-50$ \\
\hline Width of prodorsal shield & n.d. & n.d. & $48-60$ \\
\hline Length of gnathosoma & 17 & n.d. & $20-26$ \\
\hline Number of dorsal annuli & $26-36$ & $26-33$ & $38-57$ \\
\hline Distance between tubercles of setae $s c$ & n.d. & 30 & $36-38$ \\
\hline Length of seta $s c$ & n.d. & 9 & $20-24$ \\
\hline Width of female genitalia & 22 & 32 & $23-26$ \\
\hline Length of seta $c 2$ & n.d. & 16 & $29-45$ \\
\hline Length of seta $d$ & n.d. & 26 & $50-70$ \\
\hline Length of seta $e$ & n.d. & 14 & $19-23$ \\
\hline Length of seta $f$ & n.d. & 20 & $26-36$ \\
\hline Length of seta $h 2$ & n.d. & 70 & $100-110$ \\
\hline Length of seta $3 a$ & n.d. & 14 & $14-27$ \\
\hline
\end{tabular}

n.d. = no data. 
Aculus species, Aculus fraxini (Nalepa) has smooth prodorsal shield (versus shield pattern composed of lines of granules in the re-described Hungarian A. epiphyllus specimens), smooth dorsal annuli (apparently microtuberculate dorsal annuli in the Hungarian A. epiphyllus specimens), the scapular setae $s c$ as long as prodorsal shield (whereas prodorsal shield two times longer than setae $s c$ in the studied female and male population of $A$. epiphyllus), and causes leaf edge rolling (whereas no damage symptom was caused by A. epiphyllus on F. pennsylvanica) (Nalepa, 1894; Farkas, 1965).

\section{Acknowledgements}

Thanks are expressed to Dr. László Szabó (Institute of Materials and Environmental Chemistry, Research Center for Natural Sciences, Hungarian Academy of Sciences, Budapest, Hungary) for help in preparation of SEM micrographs and Mr. Ede Böszörményi (National Food Chain Safety Office, Budapest) for linguistic revision of an initial draft of the manuscript.

\section{Literature}

Amrine, J. W., Jr. and Stasny, T. A. (1994): Catalog of the Eriophyoidea (Acarina: Prostigmata) of the World. Indira Publishing House, West Bloomfield, pp. ix +798.

Amrine, J. W., Jr. and Manson, D. C. M. (1996): Preparation, mounting and descriptive study of eriophyoid mites. In: E. E. Lindquist, M. W. Sabelis and J. Bruin (eds): Eriophyoid Mites - their Biology, Natural Enemies and Control. World Crop Pests, 6. Elsevier Scientific Publishing, Amsterdam, pp. 383-396.

Amrine, J. W. Jr., Stasny, T. A. H. and Flechtmann, C. H. W. (2003): Revised Keys to World Genera of Eriophyoidea (Acari: Prostigmata). Indira Publishing House, West Bloomfield, iv +244 p.

Chetverikov, P. E. and Craemer, C. (2015): Gnathosomal interlocking apparatus and remarks on functional morphology of frontal lobes of eriophyoid mites (Acariformes, Eriophyoidea). Experimental and Applied Acarology, 66, 187-202. http://dx.doi.org/10.1007/s10493-015-9906-3

Csiszár, Á. and Bartha, D. (2004): Amerikai kőris (Fraxinus pennsylvanica Marsh.). [Green ash (Fraxinus pennsylvanica Marsh.)]. In: B. Mihály and Z. Botta-Dukát, (eds): Biológiai inváziók Magyarországon. Özönnövények. [Biological invasions in Hungary. Invasive plants.] TermészetBÚVÁR Alapítvány Kiadó, Budapest, 131-142. (in Hungarian)

Davis, R., Flechtmann, C. H. W., Boczek, J. H. and Barké, H. E. (1982): Catalogue of Eriophyid Mites (Acari: Eriophyoidea). Warsaw Agricultural University Press, Warsaw, 254 p.

Farkas, H. (1965): Spinnentiere, Eriophyidae (Gallmilben). In: P. Brohmer, P. Ehrmann und G. Ulmer (eds): Die tierwelt Mitteleuropas. Verlag von Quelle and Meyer, Leipzig, 1-155.

Farkas, H. (1966): Gubacsatkák - Eriophyidae. In: Fauna Hungariae: [Gall Mites - Eriophyidae. In: Animals of Hungary]. Akadémiai Kiadó, Budapest, 81, 1-164.

Keifer, H. H. (1959): Eriophyid Studies XXVII. Occasional Papers 1. Bureau of Entomology, California Department of Agriculture, 1-18.

Keifer, H. H. (1975): Eriophyoidea Nalepa. In: L. R. Jeppson, H. H. Keifer and E. W. Baker (eds): Mites Injurious to Economic Plants. University of California Press, Berkeley, Los Angeles, London. pp. 327-533.

Király, G. (ed.) (2009): Új magyar füvészkönyv. Magyarország hajtásos növényei. Határozókulcsok. [New Hungarian Herbal. The Vascular Plants of Hungary. Identification Key.]. Aggteleki Nemzeti Park Igazgatóság, Jósvafö, 616 p.

Korda, M. (2018): A Magyarországon inváziós növényfajok elterjedésének és elterjesztésének története I. [History of spread and propagation of invasive plants in Hungary I.] Tilia, Sopron, 19, 1-459. (in Hungarian)

Korda, M., Csóka, Gy., Szabó, Á. and Ripka, G. (2019): First occurrence and description of Aceria fraxiniflora (Felt, 1906) (Acariformes: Eriophyoidea) from Europe. Zootaxa, 4568, 293-306. http://doi.org/10.11646/ zootaxa.4568.2.5 
Lindquist, E. E. (1996): External anatomy and notation of structures. In: E. E. Lindquist, M. W. Sabelis and J. Bruin (eds): Eriophyoid Mites - their Biology, Natural Enemies and Control. World Crop Pests, 6. Elsevier Scientific Publishing, Amsterdam, pp. 3-31.

Nalepa, A. (1892): Les acarocécidies de Lorraine (Suite). In: J.-J. Kieffer (ed.): Feuille des Jeunes Naturalistes. Revue Mensuelle d'Histoire Naturelle. sér. 3, 22, 118-129.

Nalepa, A. (1894): Beiträge zur Kenntniss der Phyllocoptiden. Nova Acta Academiae Caesarae LeopoldinoCarolinae Germanicae Naturae, Halle, 61, 289-324. + 6 pls.

Nalepa, A. (1911): Eriophyiden, Gallenmilben. In: E. H. Rübsaamen (ed.): Die Zoocecidien durch Tiere erzeugte Pflanzengallen Deutschlands und ihre Bewohner. Zoologica. Original-Abhandlungen aus dem Gesamtgebiete der Zoologie (Stuttgart) 24(61), Lief 1, pp. 166-293. + 6 pls.

Ripka, G. (2007): Checklist of the eriophyoid mite fauna of Hungary (Acari: Prostigmata: Eriophyoidea). Acta Phytopathol. et Entomol. Hung. 42, 59-142.

The Plant List (2013): Version 1.1. Published on the Internet; http://www.theplantlist.org/ (accessed $21^{\text {st }}$ February 2018).

Open Access statement. This is an open-access article distributed under the terms of the Creative Commons Attribution 4.0 International License (https://creativecommons.org/licenses/by/4.0/), which permits unrestricted use, distribution, and reproduction in any medium, provided the original author and source are credited, a link to the CC License is provided, and changes - if any - are indicated. (SID_1) 
